\title{
Modulation of gene expression in endothelial cells by hyperlipaemic postprandial serum from healthy volunteers
}

\author{
Nicolas Dejeans · Jeanette A. M. Maier • \\ Igor Tauveron · Dragan Milenkovic • \\ Andrzej Mazur
}

Received: 17 June 2009/Accepted: 3 January 2010/Published online: 2 February 2010

(C) Springer-Verlag 2010

\begin{abstract}
A single high-fat challenge induces plasmatic pro-inflammatory and pro-oxidative responses in the postprandial state, even in healthy men. This period is also associated with vascular endothelial dysfunction, which is an early event in the development of cardiovascular diseases. However, knowledge about the mechanisms involved in postprandial hyperlipaemia-induced endothelial dysfunction is sparse. An objective of our study was to characterize the behaviour and gene expression of vascular endothelial cells exposed to postprandial hyperlipaemic sera. Human umbilical vein endothelial cells (HUVECs) were cultured in media containing $10 \%$ serum from healthy men withdrawn either before or $4 \mathrm{~h}$ after a high-fat challenge. Endothelial cell proliferation, adhesion and migration were then assessed. The transcriptomic profiles of endothelial cells exposed to pre and postprandial sera were also compared. Exposure to postprandial hyperlipaemic sera significantly decreased HUVEC proliferation when compared to preprandial serum $(P<0.0001)$, while no
\end{abstract}

Electronic supplementary material The online version of this article (doi:10.1007/s12263-010-0166-x) contains supplementary material, which is available to authorized users.

N. Dejeans · D. Milenkovic $(\varangle) \cdot$ A. Mazur

Unité de Nutrition Humaine, UMR1019, INRA,

Clermont-Fd/Theix, 63122 St Genès Champanelle, France

e-mail: dragan.milenkovic@clermont.inra.fr

J. A. M. Maier

Department of Preclinical Sciences LITA Vialba,

University of Milan, Via GB Grassi 74, 20157 Milan, Italy

I. Tauveron

Centre Hospitalier Universitaire de Clermont-Ferrand,

Service d'Endocrinologie et Maladies Métaboliques,

Hôpital G. Montpied, Clermont-Ferrand et Université

d'Auvergne, Faculté de Médecine, Clermont-Ferrand, France changes in migration or endothelial/monocyte interactions were observed. The transcriptomic analysis revealed changes in the expression of 675 genes, of which 431 have a known function. Among them, a set of differentially expressed genes was linked to cell cycle regulation and apoptosis and are regulated in favour of cell cycle arrest or death. This result was confirmed by measuring the induction of apoptosis after postprandial sera exposure $(P=0.011)$. Taken together, the transcriptomic results and pathway analysis showed that postprandial serum promotes apoptosis in HUVECs, potentially through the activation of the p53 network. We conclude that upon postprandial serum exposure, vascular endothelial cells transcriptionally regulate genes involved in the control of cell cycle and death to favour growth arrest and apoptosis. These findings support the hypothesis that postprandial hyperlipaemia is associated with vascular dysfunction and offer new insights into the mechanisms involved.

Keywords Postprandial hyperlipaemia .

Vascular endothelial cells · Nutrigenomics .

Apoptosis atherogenesis

\section{Introduction}

Since the early report of Zilversmit [45], the postprandial increase in blood lipids, and triacylglycerol-rich lipoproteins in particular, has been proposed to play a causal role in the aetiology of cardiovascular disease. Indeed, human studies have shown that a transient increase in blood triacylglycerol and fatty acid concentrations impairs endothelium-dependent vasodilation, which is an early event in atherogenesis [16], in healthy subjects [8]. Postprandial lipaemia has also been associated with elevated concentrations of circulating 
pro-inflammatory and pro-oxidative molecules such as tumour necrosis factor-alpha, interleukin-6, interleukin-8 and nitrotyrosine [5]. Based on these data, postprandial vascular dysfunction has been proposed to be mediated by inflammation and oxidative stress [5, 28], but the exact mechanisms remain unclear.

Recent studies using transcriptomic approaches have identified new signalling pathways and genomic signatures of atherosclerotic plaques [27, 34]. For this purpose, samples of aortic tissues and atherosclerotic plaques collected from patients and transcriptomic analysis of different stages of atheroma progression have been performed [14, 20, 31, 34]. Among the wide genomic studies found in theses studies, atherosclerotic progression was shown to be associated with the differential expression of genes involved in cell proliferation, adhesion, chemotaxis and in the organization of the cytoskeleton. These results are a significant resource for the identification of new biosignatures and new signalling pathways important in the development of cardiovascular diseases. Recently, Volger et al. [40] reported a transcriptomic study of endothelium from human large arteries isolated by laser microdissection in early and advanced stages of atherosclerosis. They showed a particular enrichment of distinct sets of chemokines and nuclear factor-kB-, p53- and transforming growth factor- $\beta$-related genes in advanced plaques. This study also revealed a broad distinction between the genomic profiles of the early and advanced stages, as shown by others in whole atherosclerotic plaques [20]. The results suggest that different stages of atheroma progression have specific transcriptomic profiles.

As postprandial hyperlipaemia-associated endothelial dysfunction could be considered a very early stage in the pathogenesis of vascular disease, we set out to establish the genomic profiles of vascular endothelial cells exposed to postprandial sera. Given the challenges of obtaining human arterial tissues, we performed an ex vivo study. To this purpose, we exposed human umbilical vein endothelial cells (HUVECs) to media containing the sera from healthy men withdrawn either before or $4 \mathrm{~h}$ after a high-fat challenge. Cellular proliferation, adhesion and migration were then assessed. The transcriptomes of endothelial cells exposed to pre and postprandial sera from each individual were compared in a pair-wise manner, thus limiting genetic and environmental confounders.

\section{Materials and methods}

Study design

The study group consisted of seven healthy normolipaemic, non-smoking males. All volunteers had normal physical examinations without any medical history of digestive, renal, cardiovascular, endocrine or chronic diseases. The physical characteristics of the subjects were (mean \pm SD) age (year) $49.3 \pm 7.6$; body weight $(\mathrm{kg}) 73.9 \pm 9.4$; BMI $\left(\mathrm{kg} / \mathrm{m}^{2}\right) \quad 25.0 \pm 2.8$; cholesterolaemia (mmol/l) $5.15 \pm$ 0.52 and triacylglycerolaemia $(\mathrm{mmol} / \mathrm{l}) 0.84 \pm 0.22$. The purpose and potential risks of the study were explained to all subjects, and their written consent was obtained before participation. The study was carried out in accordance with the guidelines of the Declaration of Helsinki after approval by the Ethics Committee of the Auvergne area. After an overnight fast of at least $12 \mathrm{~h}$, blood was withdrawn in the morning (baseline, $0 \mathrm{~h}$ ). Blood samples were collected into 6-ml EDTA-containing Vacutainer tubes. After centrifugation $\left(4,000 \mathrm{rpm}, 5 \mathrm{~min}, 20^{\circ} \mathrm{C}\right)$, plasma was collected, divided into aliquots $(250 \mu \mathrm{l})$ and immediately frozen at $-80^{\circ} \mathrm{C}$. For the sera, blood was collected in 7-ml Vacutainer glass serum tubes, placed for $1 \mathrm{~h}$ at room temperature, centrifuged $\left(4,000 \mathrm{rpm}, 15 \mathrm{~min}, 20^{\circ} \mathrm{C}\right)$ and divided into aliquots. The volunteers then received an oral fat challenge consisting of fresh cream (total lipid content $42 \mathrm{~g} / 100$ wet wt., with the percentage composition SFA/MUFA/PUFA of about 68/29/3) $50 \mathrm{~g}$ fat per $1 \mathrm{~m}^{2}$ of body surface. Body surface area was used because it is less affected by abnormal adipose mass and thus represents a better indicator of metabolic mass than body weight. The body surface area was calculated with the Dubois and Dubois formula [11]. Consumption of the cream was completed within $15 \mathrm{~min}$ from the first (baseline, $0 \mathrm{~h}$ ) blood withdrawal. Plasma and serum samples were withdrawn 2, 4, 6 and $8 \mathrm{~h}$ after the cream was consumed. The volunteers abstained from consuming any food and drinks except water during this 8 -h period.

Cell culture, proliferation, adhesion, migration and cell death

HUVECs were cultured in M199 containing 10\% foetal calf serum, endothelial cell growth supplement (ECGS) $(150 \mu \mathrm{g} / \mathrm{ml})$ and heparin $(5 \mathrm{U} / \mathrm{ml})$ on $2 \%$ gelatin-coated dishes. In all of the experiments, the cells were seeded in growth medium. After $24 \mathrm{~h}$, the medium was changed in order to expose the cells to a medium containing $10 \%$ of human pre or postprandial serum instead of $10 \%$ foetal calf serum. Proliferation assays were performed on HUVECs at low density $\left(7,500 / \mathrm{cm}^{2}\right)$, cultured in a medium containing $10 \%$ human serum. After 4 days, the cells were trypsinized, stained with trypan blue solution $(0.4 \%)$ and the viable cells were counted using a Burker chamber. All experiments were repeated at least four times for both pre and postprandial conditions for all volunteers. Migration of HUVECs cultured in the presence of pre or postprandial sera was determined using an in vitro model of wound 
repair as previously described [15]. Briefly, confluent endothelial cells were wounded and treated with hepatocyte growth factor $(\mathrm{HGF})(20 \mathrm{ng} / \mathrm{ml})$ for $18 \mathrm{~h}$. The number of cells migrating from the wound origin was counted with a light microscope at $100 \times$ magnification using a grid. The adhesion assay was performed according to Maier et al. [24] at least three times for both conditions and for each volunteer. Finally, apoptosis was assessed with the Cell Death Detection ELISAPLUS Kit (Roche, Mannheim, Germany), which qualitatively and quantitatively detects the amount of cleaved DNA/histone complexes (nucleosomes) using a sandwich enzyme immunoassay-based method. To this purpose, the cells were cultured in the presence of postprandial sera for 4 days. TNF- $\alpha(50 \mathrm{ng} / \mathrm{ml})$ was used as a positive control. Statistical analysis was carried out using SAS software (Version 8.1, SAS Institute Inc., Cary, NC, USA). For cellular proliferation, migration and adhesion assays, the statistical significance of the differences between means was assessed using the Student's $t$-test (threshold 0.05). The results of the statistical analyses are expressed as means \pm SEM.

\section{Biochemical measurements}

Cholesterol and triacylglycerol concentrations were determined enzymatically using commercial kits from BioMerieux (Charbonnières-les-Bains, France). Free fatty acids in the plasma of volunteers were measured with a kit from Wako (NEFA-C kit Unipath, Dardilly, France). The data were analysed using one-way repeated measures ANOVA. A $P$ value of $<0.05$ was considered statistically significant.

\section{Microarray procedure}

For the microarray study, total RNA was extracted from cells exposed to pre or postprandial serum for $4 \mathrm{~h}$ from five of the seven volunteers (chosen randomly). Cultured cells were preserved in RNAlater (Sigma, Steiheim, Germany) and frozen at $-20^{\circ} \mathrm{C}$ to maintain RNA integrity until the RNA was extracted. Total RNA was extracted using the RNeasy Kit (Qiagen, Courtaboeuf, France) as recommended by the manufacturer. Ten total RNA extractions were performed with cells exposed to the pre and postprandial sera for each of the five volunteers. Subsequently, RNA concentrations were assessed spectrophotometrically (260/280 absorbance ratios), and RNA quality was determined by gel electrophoresis.

The dye-swap design approach was used in the microarray study, meaning that pre and postprandial seraexposed cells were labelled in the complement colours and hybridized on the same slide, and then inversely coloured on the second slide. This dye-swap approach eliminates artefacts that result from using different dyes in the experimental and control samples. Thus, ten microarray hybridizations were completed in order to compare the transcriptomic profiles of cells exposed to postprandial sera and preprandial sera from the five volunteers. Five micrograms of total RNA were used to synthesize fluorescently labelled cDNA using the Pronto ChipShot $^{\mathrm{TM}}$ Direct Labelling Kit (Corning, Avon, France) according to the manufacturer's protocol. After purification, the quantity and labelling efficiency of the procedure were determined by quantitating the absorbance at 260, 550 and $650 \mathrm{~nm}$ using a Lambda 25 UV/VIS spectrometer (Perkin Elmer Instruments, Courtaboeuf, France). Hybridization was performed with a Pronto! ${ }^{\mathrm{TM}}$ Universal Microarray Hybridization Kit as recommended by the manufacturer. Briefly, arrays were pretreated (in pre-soak and prehybridization buffers), washed and dried by centrifugation at $500 \mathrm{rpm}$. Labelled cDNAs were dissolved in Pronto! ${ }^{\mathrm{TM}}$ Long Oligo/cDNA Hybridization Solution. Hybridizations were conducted on the RNG/MRC $25 \mathrm{k}$ human oligonucleotides microarray [22]. After heating to $95^{\circ} \mathrm{C}$ for $5 \mathrm{~min}$ and then cooling at room temperature, the mixture was applied to the slides, covered by a coverslip and incubated for $14 \mathrm{~h}$ at $42^{\circ} \mathrm{C}$. The slides were subsequently washed and dried by centrifugation at $500 \mathrm{rpm}$. The 10 slides (for a total of five independent comparisons) were scanned for both dye channels with an Affymetrix 428 Array Scanner (MWG Biotech, Roissy, France).

\section{Microarray image and statistical analyses}

The signal and background intensity values for each spot in both channels were obtained using ImaGene 6.0 software (Biodiscovery, Inc., Proteigene, Saint Marcel, France). Data were filtered using the ImaGene "empty spot" option, which automatically flags low-expressed and missing spots in order to remove them from the analyses. After log base 2 transformation, data were corrected for systemic dye bias by Lowess normalization using GeneSight 4.1 software (BioDiscovery, Inc, Proteigene, Saint Marcel, France). Ratios of the signal of postprandial cells compared to preprandial cells from the same volunteers were obtained and filtered according to their variability among the five comparisons. Statistical analyses were performed using the free R 2.1 software (http://www.r-project.org). Log ratios were analysed with an ANOVA model and a standard Student's $t$-test in order to detect differentially expressed genes between the two nutritional conditions. Probability values were adjusted using the Bonferroni correction for multiple testing at $1 \%$ to eliminate false positives. Genes identified by these criteria and with a ratio greater than 1.15 or less than $0.87(1 / 1.15)$ are referred to as the "differentially expressed genes". Differentially expressed genes 
were first annotated using the online software, DAVID [9]. They were further classified according their Gene Ontology annotation using the online Babelomics tools [1]. Pathway analysis was performed using MetaCore version 3.2 (GeneGo Inc., St Joseph, MI, USA). MetaCoreTM is based on a proprietary manually curated database of human protein-protein, protein-DNA and protein compound interactions, metabolic and signalling pathways and the effects of bioactive molecules in gene expression.

\section{Results}

Baseline fasting plasma cholesterol, triacylglycerol and free fatty acid concentrations were $6.03 \mathrm{mmol} / 1 \pm 0.43$, $0.75 \mathrm{mmol} / \mathrm{l} \pm 0.18$ and $0.41 \mathrm{mmol} / \mathrm{l} \pm 0.15$, respectively. After the oral fat challenge, the plasma triacylglycerol and free fatty acid concentrations peaked at $4 \mathrm{~h}(P<0.01)$ to gradually return to the baseline within $8 \mathrm{~h}$ (Fig. 1). We did not observe a statistically significant influence of fat ingestion on plasma cholesterol levels (Fig. 1) nor glucose level (data not shown). Since plasma free fatty acids and triacylglycerols peaked at $4 \mathrm{~h}$, we selected times $0 \mathrm{~h}(\mathrm{t} 0)$ and $4 \mathrm{~h}(\mathrm{t} 4)$ to study the behavioural and genomic response of HUVECs to postprandial hyperlipaemic sera. HUVECs were exposed to media containing $10 \%$ sera withdrawn at t0 or $\mathrm{t} 4$, and cell proliferation, adhesion and migration were then compared. Of the parameters measured, only cell proliferation was significantly affected. Indeed, exposure of the cells to postprandial hyperlipaemic sera caused a decrease in cell proliferation when compared to preprandial sera (Fig. 2) $(P<0.0001)$. Differential gene expression profiles were generated from the RNA extracted from HUVECs exposed to pre and postprandial sera from five healthy men. The comparison of the transcriptomes of HUVECs exposed to pre and postprandial sera led to the identification of 675 differentially expressed genes. Specifically, 338 genes were shown to be upregulated, and 337 genes were downregulated in the postprandial versus the preprandial condition. Among these differentially expressed genes, 431 have a known function, as revealed by ontological analyses (not shown). Ontological analyses of the results revealed that many differentially expressed genes are linked to apoptosis, cell cycle, lipid metabolism and immune and inflammatory responses. These genes are presented in Tables 1 and 2. Moreover, a great number of the differentially expressed genes have calcium ion binding capabilities (Table 3). As it may be possible that these genes are regulated in response to changes in intracellular calcium levels, we also present the differentially expressed genes linked to calcium-associated biological process and with ion channel activity in Table 3. Finally, using bioinformatics analysis (MetaCore) we identified the 10 master regulators potentially involved in the genomic regulation of gene expression in HUVECs exposed to pre and postprandial sera (Table 4). Among these, hepatocyte nuclear factor 4-alpha (HNF-4 $\alpha$ ) is the most likely to be involved in the postprandial response, as 78 genes in the set of differentially expressed genes are a target of this transcription factor. Finally, in order to confirm the apoptotic phenotype suggested by the transcriptomic results, we repeated the ex vivo experiment and measured apoptosis in the cells. We found an increase in cell death in the HUVECs exposed to postprandial sera compared to those exposed to preprandial sera $(P=0.011)$ (Fig. 3).

\section{Discussion}

Consistent with previous studies [37-39], we found that plasmatic triacylglycerols and free fatty acids increased in
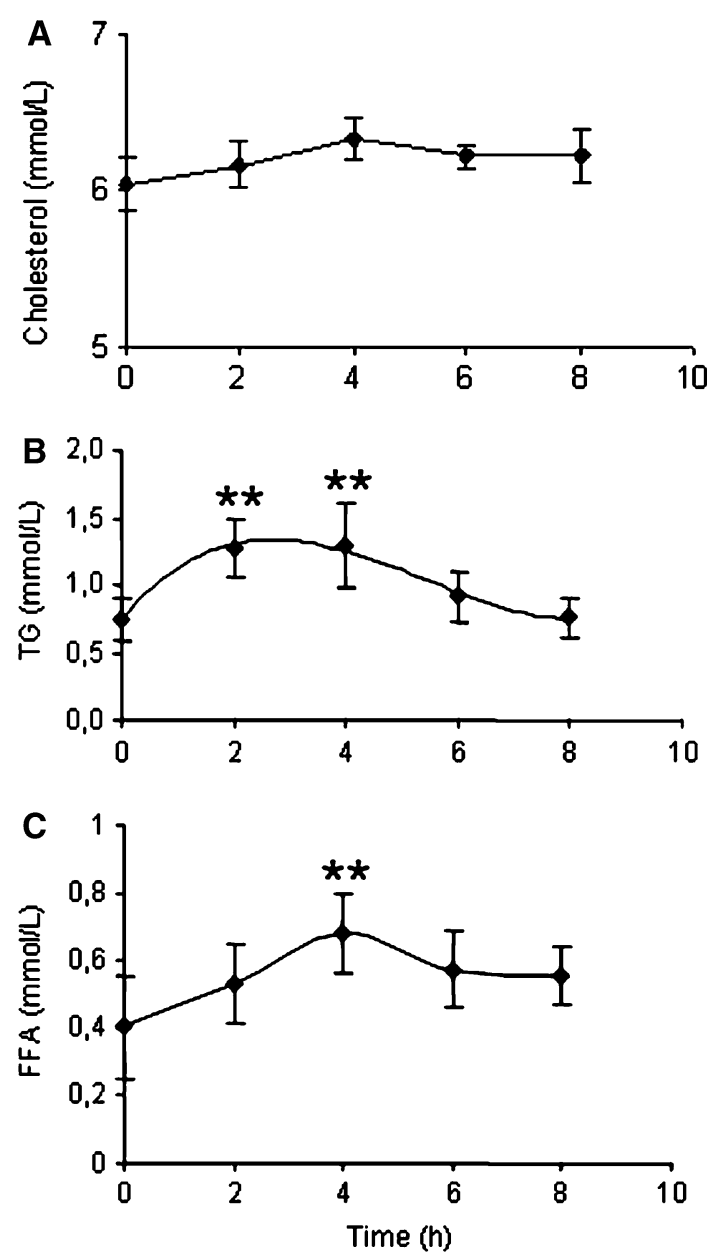

Fig. 1 Changes in postprandial plasma lipid concentrations after high-fat ingestion. The mean and standard deviation of plasma (A) cholesterol, (B) triacylglycerols (TG) and (C) free fatty acids (FFA) during an $8-\mathrm{h}$ postprandial period are shown. Values are means $\pm \mathrm{SD}, n=7$. $* * P<0.01$ 


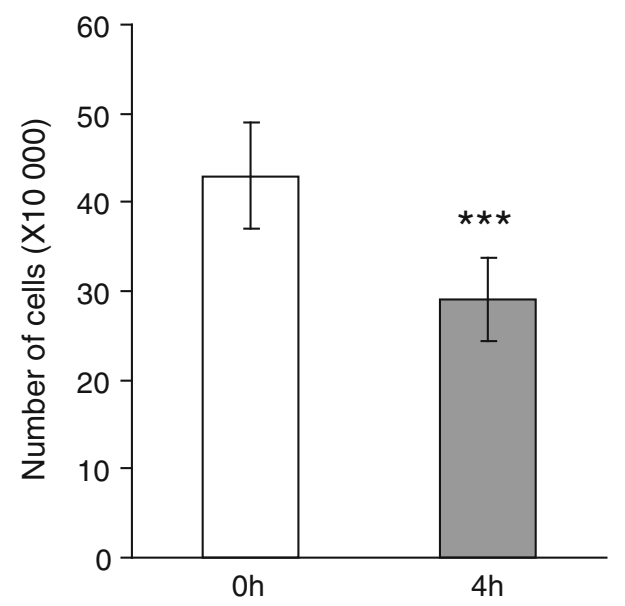

Fig. 2 Changes in HUVEC proliferation after preprandial $(0 \mathrm{~h})$ or postprandial $(4 \mathrm{~h})$ sera exposure. The means and standard deviations of cell numbers are shown. Values are means $\pm \mathrm{SD}, n=36$. $* * * P<0.0001$

plasma after a high-fat challenge in healthy men, and peaked $4 \mathrm{~h}$ after fat consumption (Fig. 1). In these studies, postprandial hyperlipaemia was shown to be associated with a general metabolic stress, characterized by the rise in oxidative stress and endothelial dysfunction. Pro-inflammatory cytokine concentrations have also been shown to be elevated during the postprandial period (4). Thus, postprandial blood after fat ingestion could be considered a mixture of molecules with the capacity to either activate or impair the functions of the endothelium, thus leading to vascular dysfunction. To study the influence of fat ingestion on vascular endothelial cells, we exposed HUVECs to sera withdrawn either before or $4 \mathrm{~h}$ after the fat challenge. HUVEC responses were then explored by evaluating: (1) proliferation, migration and endothelial/monocyte interactions and (2) modulation of gene expression as measured by transcriptomic analysis.

The first major finding of this study is the observation that HUVEC proliferation decreases (approximately 30\%) when exposed to postprandial hyperlipaemic sera (Fig. 2). To our knowledge, this is the first time that the HUVEC response to lipaemic sera has been studied. Previously, the response of HUVECs to different isolated pro-atherogenic molecules, such as oxidized LDL, has been explored. Seibold et al. [32] showed that oxidized LDL leads to either cell proliferation or apoptotic cell death, depending on the lipoprotein concentration. Other known pathogenic factors of atherosclerosis, such as oxygen-free radicals or pro-inflammatory cytokines, which are elevated in plasma during the postprandial hyperlipaemic period [5], induce programmed cellular death in endothelial cells [10]. In our study, the decreased cell number after exposure to hyperlipaemic sera was partly due to the induction of apoptosis.
Another major finding of our work is the demonstration of the modulation of genes linked to cell cycle control and the promotion of apoptosis (Table 1). Indeed, genes coding for pro-apoptotic proteins ( $c h k 2, b b c 3$, rassf5, crebbp, $c d k n 2 c$ and $b c l 3$ ) were upregulated and genes coding for anti-apoptotic and checkpoint proteins were downregulated ( $c d c 6, c d c 34, c d c 26, b c l 2 l 1$, gstpl) in HUVECs exposed to postprandial versus preprandial sera. Among these genes, chk2 encodes a protein that has the capacity to phosphorylate and, consequently, activate p53 [6]. p53 is a nuclear receptor that affects cellular functions that include transcription, DNA synthesis and repair, cell cycle arrest, senescence and apoptosis [44]. The CREB-binding protein gene, crebbp, a transcriptional co-activator that has the capacity to stimulate p53 transcriptional activity, is also overexpressed in HUVECs after hyperlipaemic serum exposure. The gene, $b b c 3$ (bcl2-binding component 3 , also known as puma) was also found to be upregulated by the transcriptomic analysis and is an essential mediator of p53induced apoptosis [42]. Thus, the concomitant upregulation of crebbp, chk2 and $b b c 3$ suggests that p53 activation occurs in HUVECs exposed to postprandial hyperlipaemic sera. This hypothesis is also supported by the identification of $\mathrm{p} 53$ as one of the three major transcription factors by the bioinformatics analysis performed with MetaCore (Table 4). Furthermore, the pathway analysis also reveals the potential implications of other regulators, such as c-Myc, which mediates p53 signal transduction [17], or c-jun/AP-1, which is implicated in the control of p53 activation [2]. Other genes involved in the induction of apoptosis are upregulated after high-fat serum exposure. Among them, rassf5 (also known as norel) encodes a specific effector that regulates the pro-apoptotic action of the oncogenic Ras protein [7]. Our transcriptome analysis suggests that various cell death pathways are upregulated. Finally, microarray analysis reveals that checkpoint proteins, such as $c d c 6, c d c 34, c d c 26$ and gstpl, are transcriptionally downregulated in the postprandial condition. Among them, the Cdc6 protein is an essential component of pre-replication complexes, which assemble at the origins of DNA replication during the G1 phase of the cell cycle [3]. Cdc6 stability is also controlled by the p53 pathway [12]. Overall, our results show that postprandial serum induces gene expression modifications in genes that are involved in the control of cell cycle and death to favour growth arrest and apoptosis in vascular endothelial cells.

Taken together, our results show that postprandial hyperlipaemic sera can induce stress and/or impair HUVEC function leading to apoptosis. This outcome could be ascribed to pro-oxidant molecules or to the cytokine, TNF- $\alpha$, which can both induce apoptosis in HUVECs [10] and have been showed to be elevated in plasma after a highfat challenge in healthy men [28]. Alternatively, the 
Table 1 Genes regulated by postprandial serum in HUVECs that are involved in cell cycle and apoptosis

\begin{tabular}{|c|c|c|c|}
\hline Gene ID & Gene symbol & Gene name & $\mathrm{FC}$ \\
\hline \multicolumn{4}{|c|}{ Cell cycle genes } \\
\hline 11200 & CHEK2 & CHK2 CHECKPOINT HOMOLOG (S. POMBE) & 1.46 \\
\hline 1031 & $\mathrm{CDKN} 2 \mathrm{C}$ & $\begin{array}{l}\text { CYCLIN-DEPENDENT KINASE INHIBITOR 2C (P18, } \\
\text { INHIBITS CDK4) }\end{array}$ & 1.31 \\
\hline 10769 & PLK2 & POLO-LIKE KINASE 2 (DROSOPHILA) & 1.31 \\
\hline 51696 & HECA & HEADCASE HOMOLOG (DROSOPHILA) & 1.30 \\
\hline 10459 & MAD2L2 & MAD2 MITOTIC ARREST DEFICIENT-LIKE 2 (YEAST) & 1.24 \\
\hline 5719 & PSMD13 & $\begin{array}{l}\text { PROTEASOME (PROSOME, MACROPAIN) 26S SUBUNIT, } \\
\text { NON-ATPASE, } 13\end{array}$ & 1.21 \\
\hline 602 & BCL3 & B-CELL CLL/LYMPHOMA 3 & 1.19 \\
\hline 83593 & RASSF5 & RAS ASSOCIATION (RALGDS/AF-6) DOMAIN FAMILY 5 & 1.16 \\
\hline 8451 & CUL4A & CULLIN 4A & 0.85 \\
\hline 990 & CDC6 & $\begin{array}{l}\text { CDC6 CELL DIVISION CYCLE } 6 \text { HOMOLOG (S. } \\
\text { CEREVISIAE) }\end{array}$ & 0.85 \\
\hline 2672 & GFI1 & GROWTH FACTOR INDEPENDENT 1 & 0.84 \\
\hline 5228 & PGF & $\begin{array}{l}\text { PLACENTAL GROWTH FACTOR, VASCULAR } \\
\text { ENDOTHELIAL GROWTH FACTOR-RELATED PROTEIN }\end{array}$ & 0.84 \\
\hline 997 & CDC34 & CELL DIVISION CYCLE 34 & 0.83 \\
\hline 140690 & CTCFL & CCCTC-BINDING FACTOR (ZINC FINGER PROTEIN)-LIKE & 0.81 \\
\hline 11040 & PIM2 & PIM-2 ONCOGENE & 0.78 \\
\hline 2935 & GSPT1 & G1 TO S PHASE TRANSITION 1 & 0.71 \\
\hline 10634 & GAS2L1 & GROWTH ARREST-SPECIFIC 2 LIKE 1 & 0.69 \\
\hline \multicolumn{4}{|l|}{ Apoptosis } \\
\hline 27113 & $\mathrm{BBC} 3$ & BCL2-BINDING COMPONENT 3 & 1.27 \\
\hline 597 & BCL2A1 & BCL2-RELATED PROTEIN A1 & 1.27 \\
\hline 83593 & RASSF5 & RAS ASSOCIATION (RALGDS/AF-6) DOMAIN FAMILY 5 & 1.16 \\
\hline 117584 & RFFL & RING FINGER AND FYVE-LIKE DOMAIN CONTAINING 1 & 1.16 \\
\hline 1917 & $\mathrm{EEF} 1 \mathrm{~A} 2$ & $\begin{array}{l}\text { EUKARYOTIC TRANSLATION ELONGATION FACTOR } 1 \\
\text { ALPHA } 2\end{array}$ & 0.86 \\
\hline 1616 & DAXX & DEATH-ASSOCIATED PROTEIN 6 & 0.85 \\
\hline 8451 & CUL4A & CULLIN 4A & 0.85 \\
\hline 9093 & DNAJA3 & DNAJ (HSP40) HOMOLOG, SUBFAMILY A, MEMBER 3 & 0.85 \\
\hline 598 & BCL2L1 & BCL2-LIKE 1 & 0.84 \\
\hline 6885 & MAP3K7 & $\begin{array}{l}\text { MITOGEN-ACTIVATED PROTEIN KINASE KINASE KINASE } \\
7\end{array}$ & 0.83 \\
\hline 56616 & DIABLO & DIABLO HOMOLOG (DROSOPHILA) & 0.81 \\
\hline 8477 & GPR65 & G PROTEIN-COUPLED RECEPTOR 65 & 0.80 \\
\hline 11040 & PIM2 & PIM-2 ONCOGENE & 0.78 \\
\hline 246184 & $\mathrm{CDC} 26$ & CELL DIVISION CYCLE 26 & 0.76 \\
\hline 2935 & GSPT1 & G1 TO S PHASE TRANSITION 1 & 0.71 \\
\hline
\end{tabular}

apoptosis of HUVECs could be due to low levels of growth and survival factors in postprandial sera. Indeed, cellular survival is dependent upon the availability of growth factors that can inhibit intrinsic programmed cell death. Among these growth factors, interleukin-3 (IL-3) and placental growth (PlGF) factor are transcriptionally downregulated in our study (Table 2). IL-3 has been showed to inhibit apoptosis through the activation of different signalling pathways $[19,35]$ and can induce vascular endothelial cell proliferation in vitro [4]. PIGF, a member of the VEGF family, is angiogenic and promotes endothelial cell proliferation in vitro [30]. Therefore, the inhibition of HUVEC proliferation observed in this study could be mediated, at least in part, by the downregulation of IL-3 or PlGF.

Intracellular concentrations of potassium and calcium ions also play an important role in apoptosis $[21,26]$. The microarray analysis of vascular endothelial cells exposed to pre or postprandial sera indicates the importance of a set of 
Table 2 Genes regulated by postprandial serum in HUVECs that are involved in lipid metabolism and immune and inflammatory responses

\begin{tabular}{|c|c|c|c|}
\hline Gene ID & Gene symbol & Gene name & $\mathrm{FC}$ \\
\hline \multicolumn{4}{|c|}{ Lipid metabolism genes } \\
\hline 1577 & CYP3A5 & $\begin{array}{l}\text { CYTOCHROME P450, FAMILY 3, SUBFAMILY A, } \\
\text { POLYPEPTIDE } 5\end{array}$ & 1.28 \\
\hline 79966 & SCD5 & STEAROYL-COA DESATURASE 5 & 1.27 \\
\hline 35 & ACADS & $\begin{array}{l}\text { ACYL-COENZYME A DEHYDROGENASE, C-2 TO C-3 } \\
\text { SHORT CHAIN }\end{array}$ & 1.23 \\
\hline 80011 & NIP30 & NEFA-INTERACTING NUCLEAR PROTEIN NIP30 & 1.22 \\
\hline 8443 & GNPAT & GLYCERONEPHOSPHATE O-ACYLTRANSFERASE & 1.21 \\
\hline 3158 & HMGCS2 & $\begin{array}{l}\text { 3-HYDROXY-3-METHYLGLUTARYL-COENZYME A } \\
\text { SYNTHASE } 2 \text { (MITOCHONDRIAL) }\end{array}$ & 1.21 \\
\hline 54965 & PIGX & PHOSPHATIDYLINOSITOL GLYCAN, CLASS X & 1.21 \\
\hline 1387 & CREBBP & $\begin{array}{l}\text { CREB-BINDING PROTEIN (RUBINSTEIN-TAYBI } \\
\text { SYNDROME) }\end{array}$ & 1.20 \\
\hline 8856 & NR1I2 & $\begin{array}{l}\text { NUCLEAR RECEPTOR SUBFAMILY 1, GROUP I, } \\
\text { MEMBER } 2 \text { (PXR) }\end{array}$ & 1.20 \\
\hline 6817 & SULT1A1 & $\begin{array}{l}\text { SULFOTRANSFERASE FAMILY, CYTOSOLIC, 1A, } \\
\text { PHENOL-PREFERRING, MEMBER } 1\end{array}$ & 1.18 \\
\hline 34 & ACADM & $\begin{array}{l}\text { ACYL-COENZYME A DEHYDROGENASE, C-4 TO C- } \\
12 \text { STRAIGHT CHAIN }\end{array}$ & 1.16 \\
\hline 8087 & FXR1 & $\begin{array}{l}\text { FRAGILE X MENTAL RETARDATION, AUTOSOMAL } \\
\text { HOMOLOG } 1\end{array}$ & 1.16 \\
\hline 85320 & $\mathrm{ABCC} 11$ & ATP-BINDING CASSETTE TRANSPORTER MRP8 & 0.86 \\
\hline 3712 & IVD & ISOVALERYL COENZYME A DEHYDROGENASE & 0.85 \\
\hline 9619 & ABCG1 & $\begin{array}{l}\text { ATP-BINDING CASSETTE, SUB-FAMILY G (WHITE), } \\
\text { MEMBER } 1\end{array}$ & 0.85 \\
\hline 1545 & CYP1B1 & $\begin{array}{l}\text { CYTOCHROME P450, FAMILY 1, SUBFAMILY B, } \\
\text { POLYPEPTIDE } 1\end{array}$ & 0.85 \\
\hline 7804 & LRP8 & $\begin{array}{l}\text { LOW-DENSITY LIPOPROTEIN RECEPTOR-RELATED } \\
\text { PROTEIN 8, APOLIPOPROTEIN E RECEPTOR }\end{array}$ & 0.84 \\
\hline 9420 & CYP7B1 & $\begin{array}{l}\text { CYTOCHROME P450, FAMILY 7, SUBFAMILY B, } \\
\text { POLYPEPTIDE } 1\end{array}$ & \\
\hline 10026 & PIGK & PHOSPHATIDYLINOSITOL GLYCAN, CLASS K & 0.83 \\
\hline 345 & APOC3 & APOLIPOPROTEIN C-III & 0.82 \\
\hline 50487 & PLA2G3 & PHOSPHOLIPASE A2, GROUP III & 0.79 \\
\hline 10351 & ABCA8 & $\begin{array}{l}\text { ATP-BINDING CASSETTE, SUB-FAMILY A (ABC1), } \\
\text { MEMBER } 8\end{array}$ & 0.75 \\
\hline 347735 & SERINC2 & SERINE INCORPORATOR 2 & 0.73 \\
\hline \multicolumn{4}{|c|}{ Immune and inflammatory response genes } \\
\hline 8581 & LY6D & LYMPHOCYTE ANTIGEN 6 COMPLEX, LOCUS D & 1.41 \\
\hline 8029 & CUBN & $\begin{array}{l}\text { CUBILIN (INTRINSIC FACTOR-COBALAMIN } \\
\text { RECEPTOR) }\end{array}$ & 1.34 \\
\hline 4033 & LRMP & LYMPHOID-RESTRICTED MEMBRANE PROTEIN & 1.31 \\
\hline 221938 & MMD2 & $\begin{array}{l}\text { MONOCYTE TO MACROPHAGE DIFFERENTIATION- } \\
\text { ASSOCIATED } 2\end{array}$ & 1.29 \\
\hline 462 & SERPINC1 & $\begin{array}{l}\text { SERPIN PEPTIDASE INHIBITOR, CLADE C } \\
\text { (ANTITHROMBIN), MEMBER } 1\end{array}$ & 1.24 \\
\hline 2833 & CXCR3 & CHEMOKINE (C-X-C MOTIF) RECEPTOR 3 & 1.23 \\
\hline 5732 & PTGER2 & $\begin{array}{l}\text { PROSTAGLANDIN E RECEPTOR } 2 \text { (SUBTYPE EP2), } \\
\text { 53KDA }\end{array}$ & 1.21 \\
\hline 8993 & PGLYRP1 & PEPTIDOGLYCAN RECOGNITION PROTEIN 1 & 1.20 \\
\hline 23446 & SLC44A1 & SOLUTE CARRIER FAMILY 44, MEMBER 1 & 1.18 \\
\hline 57549 & IGSF9 & IMMUNOGLOBULIN SUPERFAMILY, MEMBER 9 & 1.18 \\
\hline
\end{tabular}


Table 2 continued

\begin{tabular}{|c|c|c|c|}
\hline Gene ID & Gene symbol & Gene name & $\mathrm{FC}$ \\
\hline 10410 & IFITM3 & $\begin{array}{l}\text { INTERFERON-INDUCED TRANSMEMBRANE } \\
\text { PROTEIN } 3 \text { (1-8U) }\end{array}$ & 1.18 \\
\hline 7441 & VPREB1 & PRE-B LYMPHOCYTE GENE 1 & 1.17 \\
\hline 51156 & SERPINA10 & $\begin{array}{l}\text { SERPIN PEPTIDASE INHIBITOR, CLADE A (ALPHA-1 } \\
\text { ANTIPROTEINASE, ANTITRYPSIN), MEMBER } 10\end{array}$ & 1.16 \\
\hline 2151 & F2RL2 & $\begin{array}{l}\text { COAGULATION FACTOR II (THROMBIN) } \\
\text { RECEPTOR-LIKE } 2\end{array}$ & 1.16 \\
\hline 56123 & PCDHB13 & PROTOCADHERIN BETA 13 & 0.86 \\
\hline 5737 & PTGFR & PROSTAGLANDIN F RECEPTOR (FP) & 0.86 \\
\hline 3565 & IL4 & INTERLEUKIN 4 & 0.85 \\
\hline 9332 & CD163 & CD163 ANTIGEN & 0.85 \\
\hline 990 & CDC6 & $\begin{array}{l}\text { CDC6 CELL DIVISION CYCLE } 6 \text { HOMOLOG (S. } \\
\text { CEREVISIAE) }\end{array}$ & 0.85 \\
\hline 8277 & TKTL1 & TRANSKETOLASE-LIKE 1 & 0.85 \\
\hline 5228 & PGF & $\begin{array}{l}\text { PLACENTAL GROWTH FACTOR, VASCULAR } \\
\text { ENDOTHELIAL GROWTH FACTOR-RELATED } \\
\text { PROTEIN }\end{array}$ & 0.84 \\
\hline 3433 & IFIT2 & $\begin{array}{l}\text { INTERFERON-INDUCED PROTEIN WITH } \\
\text { TETRATRICOPEPTIDE REPEATS } 2\end{array}$ & 0.83 \\
\hline 997 & $\mathrm{CDC} 34$ & CELL DIVISION CYCLE 34 & 0.83 \\
\hline 6349 & CCL3L3 & CHEMOKINE (C-C MOTIF) LIGAND 3-LIKE 1 & 0.82 \\
\hline 64072 & $\mathrm{CDH} 23$ & CADHERIN-LIKE 23 & 0.81 \\
\hline 11027 & LILRA2 & $\begin{array}{l}\text { LEUCOCYTE IMMUNOGLOBULIN-LIKE RECEPTOR, } \\
\text { SUBFAMILY A (WITH TM DOMAIN), MEMBER } 2\end{array}$ & 0.81 \\
\hline 3562 & IL3 & $\begin{array}{l}\text { INTERLEUKIN } 3 \text { (COLONY-STIMULATING FACTOR, } \\
\text { MULTIPLE) }\end{array}$ & 0.81 \\
\hline 79626 & TNFAIP8L2 & $\begin{array}{l}\text { TUMOUR NECROSIS FACTOR, ALPHA-INDUCED } \\
\text { PROTEIN 8-LIKE } 2\end{array}$ & 0.80 \\
\hline 148170 & CDC42EP5 & $\begin{array}{l}\text { CDC42 EFFECTOR PROTEIN (RHO GTPASE } \\
\text { BINDING) } 5\end{array}$ & 0.77 \\
\hline 23418 & CRB1 & CRUMBS HOMOLOG 1 (DROSOPHILA) & 0.77 \\
\hline 246184 & $\mathrm{CDC} 26$ & CELL DIVISION CYCLE 26 & 0.76 \\
\hline 3824 & KLRD1 & $\begin{array}{l}\text { KILLER CELL LECTIN-LIKE RECEPTOR } \\
\text { SUBFAMILY D, MEMBER } 1\end{array}$ & 0.75 \\
\hline 4804 & NGFR & $\begin{array}{l}\text { NERVE GROWTH FACTOR RECEPTOR (TNFR } \\
\text { SUPERFAMILY, MEMBER 16) }\end{array}$ & 0.73 \\
\hline 26548 & ITGB1BP2 & INTEGRIN BETA 1 BINDING PROTEIN (MELUSIN) 2 & 0.67 \\
\hline 2243 & FGA & FIBRINOGEN ALPHA CHAIN & 0.66 \\
\hline 91179 & SCARF2 & SCAVENGER RECEPTOR CLASS F, MEMBER 2 & 0.63 \\
\hline
\end{tabular}

genes associated with calcium-dependent biological processes, calcium ion binding capacity or ion channel activity (Table 3). Suicidal cell death involves and requires the activation of potassium and calcium channels [21]. Indeed, increased levels of calcium may lead to the activation of $\mathrm{Ca}^{2+}$-dependent kinases or phosphatases or could lead to the increased release of cytochrome $\mathrm{c}$, thus resulting in the activation of the apoptotic pathway [21, 26]. Moreover, cellular loss of potassium favours apoptosis in a wide variety of cells. Thus, the transcriptomic regulation of genes linked to the control of intracellular ion concentrations could also explain the induction of apoptosis in HUVECs exposed to postprandial serum.

Among the 431 regulated genes with a known function, 23 are linked to lipid-related biological processes (Table 2). Some genes implicated in fatty acid degradation, including acads and acadm, which are involved in the breakdown of fatty acids and hmgcs 2 , which is involved in ketone body production from fatty acids, were found to be upregulated in the postprandial condition. These results are consistent with a metabolic response activated by HUVECs in response to the elevation of lipid uptake during fatty sera 
Table 3 Genes regulated by postprandial serum in HUVECs that are involved in calcium-associated biological process and code for proteins with calcium ion binding and ion channel activity

\begin{tabular}{|c|c|c|c|}
\hline Gene ID & Gene symbol & Gene name & FC \\
\hline \multicolumn{4}{|c|}{ Calcium-associated biological process } \\
\hline 6283 & S100A12 & S100 CALCIUM-BINDING PROTEIN A12 (CALGRANULIN C) & 1.33 \\
\hline 51475 & CABP2 & CALCIUM-BINDING PROTEIN 2 & 1.26 \\
\hline 23284 & LPHN3 & LATROPHILIN 3 & 1.21 \\
\hline 5336 & PLCG2 & PHOSPHOLIPASE C, GAMMA 2 (PHOSPHATIDYLINOSITOL-SPECIFIC) & 1.20 \\
\hline 124583 & CANT1 & CALCIUM-ACTIVATED NUCLEOTIDASE 1 & 1.16 \\
\hline 1909 & EDNRA & ENDOTHELIN RECEPTOR TYPE A & 0.84 \\
\hline \multicolumn{4}{|c|}{ Calcium ion binding } \\
\hline 8029 & CUBN & CUBILIN (INTRINSIC FACTOR-COBALAMIN RECEPTOR) & 1.34 \\
\hline 6283 & S100A12 & S100 CALCIUM-BINDING PROTEIN A12 (CALGRANULIN C) & 1.33 \\
\hline 7125 & TNNC2 & TROPONIN C TYPE 2 (FAST) & 1.28 \\
\hline 5534 & PPP3R1 & $\begin{array}{l}\text { PROTEIN PHOSPHATASE } 3 \text { (FORMERLY 2B), REGULATORY SUBUNIT } \\
\text { B, 19KDA, ALPH ... }\end{array}$ & 1.27 \\
\hline 51475 & CABP2 & CALCIUM-BINDING PROTEIN 2 & 1.26 \\
\hline 114327 & EFHC1 & HYPOTHETICAL PROTEIN FLJ10466 & 1.23 \\
\hline 5336 & PLCG2 & PHOSPHOLIPASE C, GAMMA 2 (PHOSPHATIDYLINOSITOL-SPECIFIC) & 1.20 \\
\hline 51661 & FKBP7 & FK506 BINDING PROTEIN 7 & 1.18 \\
\hline 54947 & AYTL1 & ACYLTRANSFERASE LIKE 1 & 1.17 \\
\hline 124583 & CANT1 & CALCIUM-ACTIVATED NUCLEOTIDASE 1 & 1.16 \\
\hline 5551 & PRF1 & PERFORIN 1 (PORE FORMING PROTEIN) & \\
\hline 56123 & PCDHB13 & PROTOCADHERIN BETA 13 & 0.86 \\
\hline 4324 & MMP15 & MATRIX METALLOPEPTIDASE 15 (MEMBRANE-INSERTED) & 0.85 \\
\hline 8277 & TKTL1 & TRANSKETOLASE-LIKE 1 & 0.85 \\
\hline 7804 & LRP8 & LOW-DENSITY LIPOPROTEIN RECEPTOR-RELATED PROTEIN 8 & 0.84 \\
\hline 147968 & CAPN12 & CALPAIN 12 & 0.84 \\
\hline 64072 & $\mathrm{CDH} 23$ & CADHERIN-LIKE 23 & \\
\hline 80144 & FRAS1 & KIAA1500 PROTEIN & 0.81 \\
\hline 50487 & PLA2G3 & PHOSPHOLIPASE A2, GROUP III & 0.79 \\
\hline 23418 & CRB1 & CRUMBS HOMOLOG 1 (DROSOPHILA) & 0.77 \\
\hline 92737 & DNER & DELTA-NOTCH-LIKE EGF REPEAT-CONTAINING TRANSMEMBRANE & 0.76 \\
\hline 26548 & ITGB1BP2 & INTEGRIN BETA 1 BINDING PROTEIN (MELUSIN) 2 & 0.67 \\
\hline \multicolumn{4}{|c|}{ Ion channel activity } \\
\hline 1143 & CHRNB4 & CHOLINERGIC RECEPTOR, NICOTINIC, BETA 4 & 2.51 \\
\hline 8001 & GLRA3 & GLYCINE RECEPTOR, ALPHA 3 & 1.78 \\
\hline 2890 & GRIA1 & GLUTAMATE RECEPTOR, IONOTROPIC, AMPA 1 & 1.54 \\
\hline 3761 & $\mathrm{KCNJ} 4$ & $\begin{array}{l}\text { POTASSIUM INWARDLY-RECTIFYING CHANNEL, SUBFAMILY J, } \\
\text { MEMBER } 4\end{array}$ & 1.30 \\
\hline 50801 & KCNK4 & DKFZP566E164 PROTEIN & 1.27 \\
\hline 7881 & KCNAB1 & $\begin{array}{l}\text { POTASSIUM VOLTAGE-GATED CHANNEL, SHAKER-RELATED } \\
\text { SUBFAMILY, BETA MEMBER } 1\end{array}$ & 1.19 \\
\hline 6330 & SCN4B & SODIUM CHANNEL, VOLTAGE-GATED, TYPE IV, BETA & 1.16 \\
\hline 283518 & KCNRG & POTASSIUM CHANNEL REGULATOR & 0.86 \\
\hline 146212 & KCTD19 & POTASSIUM CHANNEL TETRAMERIZATION DOMAIN CONTAINING 19 & 0.78 \\
\hline 27133 & KCNH5 & $\begin{array}{l}\text { POTASSIUM VOLTAGE-GATED CHANNEL, SUBFAMILY H (EAG- } \\
\text { RELATED), MEMBER } 5\end{array}$ & 0.76 \\
\hline 3783 & KCNN4 & $\begin{array}{l}\text { POTASSIUM INTERMEDIATE/SMALL CONDUCTANCE CALCIUM- } \\
\text { ACTIVATED CHANNEL }\end{array}$ & 0.70 \\
\hline
\end{tabular}


Table 4 Master regulators identified by transcriptomic analysis

\begin{tabular}{|c|c|c|c|c|}
\hline \multirow[t]{2}{*}{ Transcription factor } & \multirow[t]{2}{*}{ Processes } & \multirow[t]{2}{*}{$P$ value } & \multicolumn{2}{|c|}{ Regulated genes } \\
\hline & & & $\mathrm{Nb}$ & Examples \\
\hline $\mathrm{HNF}-4 \alpha$ & $\begin{array}{l}\text { Induction of apoptosis via death domain receptors } \\
\text { Energy metabolism } \\
\text { Response to chemical stimulus }\end{array}$ & $2.52 \mathrm{E}-143$ & 78 & $\begin{array}{l}\text { LRP5, APOC3, NR1I2, PXR, ABG1, } \\
\text { CIP1B1, CYP3A5 }\end{array}$ \\
\hline SP1 & $\begin{array}{l}\text { Neurotransmitter uptake } \\
\text { Intermediate filament cytoskeleton organization } \\
\text { and biogenesis } \\
\text { Ketone body biosynthetic process }\end{array}$ & $6.10 \mathrm{E}-76$ & 42 & $\begin{array}{l}\text { EDNRB, KRT16, TNNT2, PGE2R2, } \\
\text { PGF2aR, nAChR alpha-5 and alpha-4 }\end{array}$ \\
\hline P53 & $\begin{array}{l}\text { DNA damage response, signal transduction resulting } \\
\text { in induction of apoptosis } \\
\text { Regulation of mitochondrial membrane permeability } \\
\text { DNA damage response, signal transduction by p } 53 \text { class } \\
\text { mediator resulting in induction of apoptosis }\end{array}$ & $1.51 \mathrm{E}-37$ & 21 & $\begin{array}{l}\text { BCL2L1, CREBBP, CDC6, CHEK2, } \\
\text { DAXX, BCL2A1, BBC3 }\end{array}$ \\
\hline $\mathrm{c}-\mathrm{Myc}$ & $\begin{array}{l}\text { DNA damage response, signal transduction by p53 class } \\
\text { mediator resulting in induction of apoptosis } \\
\text { Induction of apoptosis by intracellular signals } \\
\text { Release of cytochrome c from mitochondria }\end{array}$ & $9.74 \mathrm{E}-36$ & 20 & BBC3, NOTCH1, BCL-3 \\
\hline AP-1 & $\begin{array}{l}\text { Cell death } \\
\text { Regulation of apoptosis } \\
\text { Regulation of apoptosis }\end{array}$ & $1.58 \mathrm{E}-28$ & 16 & CBP, DAXX, IL-3 \\
\hline c-Jun & $\begin{array}{l}\text { Regulation of survival gene product activity } \\
\text { Regulation of biological quality } \\
\text { Catecholamine uptake during transmission of nerve } \\
\text { impulse }\end{array}$ & $9.91 \mathrm{E}-27$ & 15 & CBP, DAXX, IL-3 \\
\hline CREB1 & $\begin{array}{l}\text { Regulation of nucleobase, nucleoside, nucleotide and } \\
\text { nucleic acid metabolic process } \\
\text { Regulation of cellular metabolic process } \\
\text { Regulation of transcription }\end{array}$ & $6.16 \mathrm{E}-25$ & 14 & IL-4, NPR1, SOX15 \\
\hline ESR1 & $\begin{array}{l}\text { Steroid hormone receptor signalling pathway } \\
\text { Oestrogen receptor signalling pathway } \\
\text { Regulation of transcription, DNA-dependent }\end{array}$ & $3.80 \mathrm{E}-23$ & 13 & ABCC11, CYP1B1, CYP7B1 \\
\hline HNF1-alpha & $\begin{array}{l}\text { Catecholamine transport } \\
\text { Positive regulation of cellular process } \\
\text { Catecholamine uptake during transmission of nerve } \\
\text { impulse }\end{array}$ & $3.80 \mathrm{E}-23$ & 13 & $\begin{array}{l}\text { APOC3, Fibrinogen alpha, } \\
\text { Anithrombin III }\end{array}$ \\
\hline NF-kB & $\begin{array}{l}\text { Regulation of apoptosis } \\
\text { Response to stress } \\
\text { Regulation of programmed cell death }\end{array}$ & $2.33 \mathrm{E}-21$ & 12 & SOD2, DAXX, Pim-2 \\
\hline
\end{tabular}

Transcription factors identified by MetaCore are presented. Transcription factors are organized by a major biological process in which they are involved, $P$ value assigned by MetaCore, number of genes present in the array that they potentially regulate and examples of these genes

exposure. Other genes involved in bile acid and drug detoxification are regulated in HUVECs after hyperlipaemic serum exposure. These genes include cyp3a5, cyplb1 and cyp $7 b 1$ and $a b c c 11, a b c g 1$ and abca8. Interestingly, cytochrome P450 (CYP) [23] and ATP-binding cassette (ABC) transporters have already been implicated in cardiovascular disease [29]; however, their pathological involvements are not clear. The genes coding for drug and bile acid transporters and CYP enzymes are generally regulated by the nuclear receptors FXR, PXR, CAR and HNF- $4 \alpha$ through complex and overlapping regulatory networks $[13,25]$. Among theses regulators, FXR ( $x$ r $r)$ and PXR (nrli2) were found to be upregulated in the present study (Table 2). Furthermore, special attention should be paid to $\mathrm{HNF}-4 \alpha$ regulation in our genomic study. This transcription factor was identified by MetaCore pathway analysis as the key regulator of gene expression (Table 4). HNF- $4 \alpha$ potentially regulates 78 of the genes differentially 


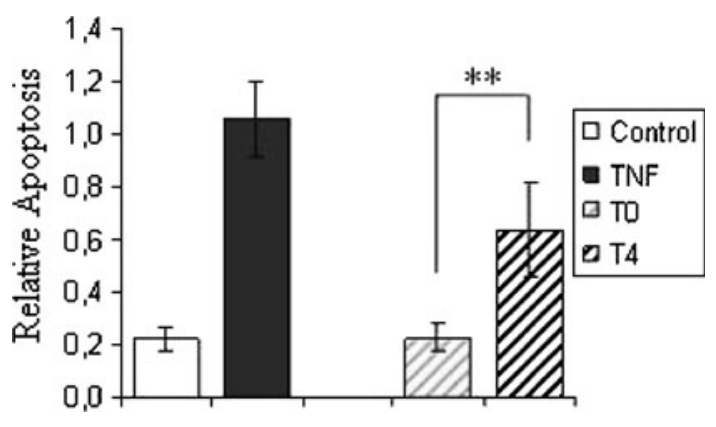

Fig. 3 Changes in apoptosis induction in HUVECs after preprandial (T0) or postprandial (T4) sera exposure. Cell death was assessed using a cell death detection ELISA kit (Roche), which detects the amount of cleaved DNA/histone complexes. Values are means $\pm \mathrm{SD}$, $n=5$. $* * P=0.011$

expressed in our study. HNF- $4 \alpha$ was first identified in the liver, where it regulates the expression of a broad number of genes involved in several different functions, including energy metabolism, xenobiotic detoxification, bile acid synthesis, serum protein production and intracellular lipid control [41]. The transcriptional activity of HNF- $4 \alpha$ transcriptional activity may be modulated by the binding of fatty acyl-CoA thioesters, fatty acyl CoA or fatty acids [18]. Gene knockout studies of $h n f-4 \alpha$ have demonstrated its role in controlling PXR expression [41]. Moreover, coactivation of HNF- $4 \alpha$ and PPAR- $\gamma$ has been linked to the increase in $f x r$ mRNA levels during fasting that results in the reduction of triglyceride production and secretion and fatty acid $\beta$-oxidation [43]. In our study, $\mathrm{HNF}-4 \alpha$ may represent a major regulator of the HUVEC metabolic response to postprandial hyperlipaemia, partially through its capacity to upregulate $f x r$ and $p x r$ expression.

Taken together, our results show that postprandial hyperlipaemia induces an apoptotic phenotype in vascular endothelial cells. Indeed, postprandial hyperlipaemic serum induces (1) a decrease in HUVEC proliferation, (2) the transcriptional regulation of major cell death-associated genes and (3) elevation of the amount of cleaved nucleosomes. This phenotype could be partially mediated by prooxidant or pro-inflammatory molecules previously shown to be elevated in plasma during the postprandial period following a high-fat challenge in healthy men. A link between endothelial apoptosis and the pathology of atherosclerosis has been previously suggested [36]. Apoptotic endothelial cells have been detected on the luminal surface of atherosclerotic coronary vessels, but not in normal vessels [36]. Endothelial apoptosis in an atherosclerotic lesion may lead to the exposure of collagen fibres. Importantly, apoptosis is suggested to play an important role in the rupture of the plaque and in thrombus formation. In conclusion, our findings support the hypothesis that postprandial hyperlipaemia is associated with an endothelial dysfunction that promotes atherogenesis.
Acknowledgments This work was supported by grants from the Fondation pour la Recherche Médicale. The authors thank Dominique Bayle and Severine Thien for their technical assistance with the biochemical measurements and Agnès Thomas and Christiane Legay for lipid analyses.

\section{References}

1. Al-Shahrour F, Minguez P, Vaquerizas JM, Conde L, Dopazo J (2005) BABELOMICS: a suite of web tools for functional annotation and analysis of groups of genes in high-throughput experiments. Nucleic Acids Res 33(Web Server issue):W460W464

2. Ameyar M, Wisniewska M, Weitzman JB (2003) A role for AP-1 in apoptosis: the case for and against. Biochimie 85(8):747-752

3. Borlado LR, Mendez J (2007) CDC6: from DNA replication to cell cycle checkpoints and oncogenesis. Carcinogenesis, 28 Nov

4. Brizzi MF, Garbarino G, Rossi PR, Pagliardi GL, Arduino C, Avanzi GC, Pegoraro L (1993) Interleukin 3 stimulates proliferation and triggers endothelial-leukocyte adhesion molecule 1 gene activation of human endothelial cells. J Clin Invest 91(6):2887-2892

5. Burdge GC, Calder PC (2005) Plasma cytokine response during the postprandial period: a potential causal process in vascular disease? Br J Nutr 93(1):3-9

6. Coutts AS, La Thangue NB (2005) The p53 response: emerging levels of co-factor complexity. Biochem Biophys Res Commun 331(3):778-785

7. Cox AD, Der CJ (2003) The dark side of Ras: regulation of apoptosis. Oncogene 22(56):8999-9006

8. de Koning EJ, Rabelink TJ (2002) Endothelial function in the post-prandial state. Atheroscler Suppl 3(1):11-16

9. Dennis G Jr, Sherman BT, Hosack DA, Yang J, Gao W, Lane HC, Lempicki RA (2003) DAVID: database for annotation, visualization, and integrated discovery. Genome Biol 4(5):P3

10. Dimmeler S, Hermann C, Zeiher AM (1998) Apoptosis of endothelial cells. Contribution to the pathophysiology of atherosclerosis? Eur Cytokine Netw 9(4):697-698

11. Du Bois D, Du Bois EF (1989) A formula to estimate the approximate surface area if height and weight be known. 1916. Nutrition 5(5)

12. Duursma A, Agami R (2005) p53-Dependent regulation of Cdc6 protein stability controls cellular proliferation. Mol Cell Biol 25(16):6937-6947

13. Eloranta JJ, Kullak-Ublick GA (2005) Coordinate transcriptional regulation of bile acid homeostasis and drug metabolism. Arch Biochem Biophys 433(2):397-412

14. Faber BC, Cleutjens KB, Niessen RL, Aarts PL, Boon W, Greenberg AS, Kitslaar PJ, Tordoir JH, Daemen MJ (2001) Identification of genes potentially involved in rupture of human atherosclerotic plaques. Circ Res 89(6):547-554

15. Garfinkel S, Hu X, Prudovsky IA, McMahon GA, Kapnik EM, McDowell SD, Maciag T (1996) FGF-1-dependent proliferative and migratory responses are impaired in senescent human umbilical vein endothelial cells and correlate with the inability to signal tyrosine phosphorylation of fibroblast growth factor receptor-1 substrates. J Cell Biol 134(3):783-791

16. Harrison DG (1993) Endothelial dysfunction in the coronary microcirculation: a new clinical entity or an experimental finding? J Clin Invest 91(1):1-2

17. Ho JS, Ma W, Mao DY, Benchimol S (2005) p53-Dependent transcriptional repression of c-myc is required for $\mathrm{G} 1$ cell cycle arrest. Mol Cell Biol 25(17):7423-7431 
18. Jump DB, Botolin D, Wang Y, Xu J, Christian B, Demeure O (2005) Fatty acid regulation of hepatic gene transcription. J Nutr 135(11):2503-2506

19. Khaled AR, Reynolds DA, Young HA, Thompson CB, Muegge K, Durum SK (2001) Interleukin-3 withdrawal induces an early increase in mitochondrial membrane potential unrelated to the Bcl-2 family. Roles of intracellular $\mathrm{pH}$, ADP transport, and F(0)F(1)-ATPase. J Biol Chem 276(9):6453-6462

20. King JY, Ferrara R, Tabibiazar R, Spin JM, Chen MM, Kuchinsky A, Vailaya A, Kincaid R, Tsalenko A, Deng DX, Connolly A, Zhang P, Yang E, Watt C, Yakhini Z, Ben-Dor A, Adler A, Bruhn L, Tsao P, Quertermous T, Ashley EA (2005) Pathway analysis of coronary atherosclerosis. Physiol Genomics 23(1):103-118

21. Lang F, Foller M, Lang K, Lang P, Ritter M, Vereninov A, Szabo I, Huber SM, Gulbins E (2007) Cell volume regulatory ion channels in cell proliferation and cell death. Methods Enzymol 428:209-225

22. Le Brigand K, Russell R, Moreilhon C, Rouillard JM, Jost B, Amiot F, Magnone V, Bole-Feysot C, Rostagno P, Virolle V, Defamie V, Dessen P, Williams G, Lyons P, Rios G, Mari B, Gulari E, Kastner P, Gidrol X, Freeman TC, Barbry P (2006) An open-access long oligonucleotide microarray resource for analysis of the human and mouse transcriptomes. Nucleic Acids Res 34(12):e87

23. Luoma PV (2007) Cytochrome P450-physiological key factor against cholesterol accumulation and the atherosclerotic vascular process. Ann Med 39(5):359-370

24. Maier JA, Malpuech-Brugere C, Zimowska W, Rayssiguier Y, Mazur A (2004) Low magnesium promotes endothelial cell dysfunction: implications for atherosclerosis, inflammation and thrombosis. Biochim Biophys Acta 1689(1):13-21

25. Makishima M (2005) Nuclear receptors as targets for drug development: regulation of cholesterol and bile acid metabolism by nuclear receptors. J Pharmacol Sci 97(2):177-183

26. McConkey DJ, Orrenius S (1997) The role of calcium in the regulation of apoptosis. Biochem Biophys Res Commun 239(2):357-366

27. Nanni L, Romualdi C, Maseri A, Lanfranchi G (2006) Differential gene expression profiling in genetic and multifactorial cardiovascular diseases. J Mol Cell Cardiol 41(6):934-948

28. Nappo F, Esposito K, Cioffi M, Giugliano G, Molinari AM, Paolisso G, Marfella R, Giugliano D (2002) Postprandial endothelial activation in healthy subjects and in type 2 diabetic patients: role of fat and carbohydrate meals. J Am Coll Cardiol 39(7):1145-1150

29. Oram JF, Vaughan AM (2006) ATP-Binding cassette cholesterol transporters and cardiovascular disease. Circ Res 99(10):10311043

30. Otrock ZK, Makarem JA, Shamseddine AI (2007) Vascular endothelial growth factor family of ligands and receptors: review. Blood Cells Mol Dis 38(3):258-268

31. Randi AM, Biguzzi E, Falciani F, Merlini P, Blakemore S, Bramucci E, Lucreziotti S, Lennon M, Faioni EM, Ardissino D,
Mannucci PM (2003) Identification of differentially expressed genes in coronary atherosclerotic plaques from patients with stable or unstable angina by cDNA array analysis. J Thromb Haemost 1(4):829-835

32. Seibold S, Schurle D, Heinloth A, Wolf G, Wagner M, Galle J (2004) Oxidized LDL induces proliferation and hypertrophy in human umbilical vein endothelial cells via regulation of p27Kip1 expression: role of RhoA. J Am Soc Nephrol 15(12):3026-3034

33. Seo D, Ginsburg GS, Goldschmidt-Clermont PJ (2006) Gene expression analysis of cardiovascular diseases: novel insights into biology and clinical applications. J Am Coll Cardiol 48(2): 227-235

34. Seo D, Wang T, Dressman H, Herderick EE, Iversen ES, Dong C, Vata K, Milano CA, Rigat F, Pittman J, Nevins JR, West M, Goldschmidt-Clermont PJ (2004) Gene expression phenotypes of atherosclerosis. Arterioscler Thromb Vasc Biol 24(10):19221927

35. Thomas J, Leverrier Y, Marvel J (1998) Bcl-X is the major pleiotropic anti-apoptotic gene activated by retroviral insertion mutagenesis in an IL-3 dependent bone marrow derived cell line. Oncogene 16(11):1399-1408

36. Tricot O, Mallat Z, Heymes C, Belmin J, Leseche G, Tedgui A (2000) Relation between endothelial cell apoptosis and blood flow direction in human atherosclerotic plaques. Circulation 101(21):2450-2453

37. Tsai WC, Li YH, Lin CC, Chao TH, Chen JH (2004) Effects of oxidative stress on endothelial function after a high-fat meal. Clin Sci (Lond) 106(3):315-319

38. van Oostrom AJ, Sijmonsma TP, Verseyden C, Jansen EH, de Koning EJ, Rabelink TJ, Castro Cabezas M (2003) Postprandial recruitment of neutrophils may contribute to endothelial dysfunction. J Lipid Res 44(3):576-583

39. Vogel RA, Corretti MC, Plotnick GD (1997) Effect of a single high-fat meal on endothelial function in healthy subjects. Am J Cardiol 79(3):350-354

40. Volger OL, Fledderus JO, Kisters N, Fontijn RD, Moerland PD, Kuiper J, van Berkel TJ, Bijnens AP, Daemen MJ, Pannekoek H, Horrevoets AJ (2007) Distinctive expression of chemokines and transforming growth factor-beta signaling in human arterial endothelium during atherosclerosis. Am J Pathol 171(1):326-337

41. Watt AJ, Garrison WD, Duncan SA (2003) HNF4: a central regulator of hepatocyte differentiation and function. Hepatology 37(6):1249-1253

42. Yu J, Zhang L (2003) No PUMA, no death: implications for p53-dependent apoptosis. Cancer Cell 4(4):248-249

43. Zhang Y, Castellani LW, Sinal CJ, Gonzalez FJ, Edwards PA (2004) Peroxisome proliferator-activated receptor-gamma coactivator 1alpha (PGC-1alpha) regulates triglyceride metabolism by activation of the nuclear receptor FXR. Genes Dev 18(2):157169

44. Zhou BB, Elledge SJ (2000) The DNA damage response: putting checkpoints in perspective. Nature 408(6811):433-439

45. Zilversmit DB (1979) Atherogenesis: a postprandial phenomenon. Circulation 60(3):473-485 